\title{
The role of social networks in agricultural innovation: the Sutherland reclamations and the Fowlers steam plough, c.1855-c.1885
}

\section{Section I: Introduction}

'With his titanic steam ploughs and other marvellous appliances for subduing and transforming the stony waste and wilderness, the duke conquers the stubborn soil of the North as triumphantly as the first great Iron Duke conquered the armies of France., ${ }^{1}$

The nineteenth century saw an explosion in creativity and innovation, often applied to and motivated by an urge to improve, refine and make more efficient industrial and agricultural processes. $^{2}$ Numerous and detailed studies abound on the most famous and influential of these innovations; the Spinning Jenny, for instance, or the steam printing press. ${ }^{3}$ There were many innovations in the field of agriculture also, supported by the sponsorship of societies and associations and, in the 1850s and 1860s, by strong investment under High Farming. This article examines one of these innovations, the steam plough, with reference to its application in the Scottish Highlands in the 1870s and 1880s. ${ }^{4}$ In particular, it illuminates the social networks which lay behind the development and utilisation of the steam plough in the rural Highland context, delineating how aristocratic, religious and local networks combined to

\footnotetext{
${ }^{1}$ Inverness Courier, 6 Aug. 1874.

2 P. K. O'Brien, 'Agriculture and the Industrial Revolution,' Economic History Review, 30 (1977); P. Mathias, The First Industrial Nation: the economic history of Britain, 1700-1914 (London, 1969), pp. 308-19; S. Macdonald, 'Agricultural improvement and the neglected labourer,' Agricultural History Review, 31 (1982), p.81; S. A. Caunce, 'Mechanisation and society in English agriculture: the experience of the North-East, 18501914,' Rural History, 17:1 (2006), pp. 23-45.

${ }^{3}$ See for instance, A. Fyfe, Steam-powered knowledge: William Chambers and the business of publishing, 18201860 (Chicago, 2012); S. Hylton, The Grand Experiment: the birth of the railway age: 1820-45 (Surrey, 2007), pp. 145-162.

${ }^{4}$ Please see for a comparative case study S. Macdonald, 'The progress of the early threshing machine,' Agricultural History Review, 13 (1975), pp. 63-77.
} 
have a major impact on rural society in Sutherland and beyond. ${ }^{5}$ Indeed, in the case of the steam plough, its most successful applications in the long term were in Germany, Australia and South Africa, mainly due to the favourable environmental conditions found there. ${ }^{6}$

This article takes as its period of study the 1860 s to the 1880 s, an age of unfettered confidence. ${ }^{7}$ By the 1860 s this confidence had been part of society even in the remote and rural fringes of the country, not least because the great landowners of England, Wales, Ireland and Scotland had long been investors in the new industrial economy and much innovation was concentrated in agricultural technologies. ${ }^{8}$ One of the leading families in both rural and industrial British society were the Leveson-Gowers, earls and dukes of Sutherland, and of particular focus in this paper, George William Sutherland Leveson-Gower, $3^{\text {rd }}$ Duke of Sutherland (1828-1892). ${ }^{9}$ The $3^{\text {rd }}$ Duke presided over a large but fractured and various fortune; from 1 million acres of relatively poor-quality land in the north of Scotland, to estates in Yorkshire, Shropshire and Staffordshire, to significant industrial and imperial investments. The $3^{\text {rd }}$ Duke was a multi-millionaire and in a position to attempt expensive experiments to improve the profitability of his land and indulge his personal passion for the

\footnotetext{
${ }^{5}$ H. Bonnett, Farming with Steam, (Aylesbury, 1974), p. 10.

${ }^{6}$ M. R. Lane, The Story of the Steam Plough Works: Fowlers of Leeds (London, 1979), pp. 66-7. In all, Fowlers set up branches in France, Spain, Italy, Germany, Czechoslovakia, Hungary, India, the East Indies, South Africa, Australia and New Zealand; the records of these operations are in the Fowlers archive at the Museum of English Rural Life [hereafter MERL], TR FOW, AC8/1-18, AC7/1, AC8/46, AC8/48-50, CO1/9-14.

${ }^{7}$ Mathias, The First Industrial Nation; J. Sheal, 'Land improvement and reclamation: the experiences of the First World War in England and Wales,' Agricultural History Review, 24 (1976), pp. 110-25.

${ }^{8}$ For example, the Marquis of Bute (docks), Lord Londonderry (mining), the dukes of Buccleuch (mining); see G. E. Mingay, Land and Society in England, 1750-1980 (London, 1994), pp. 195-6; Caunce, 'Mechanisation and Society,' p. 24; J. D. Chambers and G. E. Mingay, The Agricultural Revolution, 1750-1880 (London, 1966), pp. 170-95; D. B. Grigg, English Agriculture: an historical perspective, (London, 1989); N. Hart and R. Quinault (eds), Land and Society in Britain, 1700-1914: essays in honour of F. M. L. Thompson (Manchester, 1996).

${ }^{9}$ E. Richards, 'Gower, George Granville Leveson-', first duke of Sutherland (1758-1833)', Oxford Dictionary of National Biography (Oxford, 2004).
} 
latest steam technology: the steam plough. ${ }^{10}$ The other key player in this article is John Fowlers \& Co, Leeds, the company which supplied the $3^{\text {rd }}$ Duke with the technology required for his land reclamation project. The $3^{\text {rd }}$ Duke's plan was to reclaim land perceived to be 'waste' (that is, unproductive for crops or grazing) into fertile arable acres capable of growing the fodder crops necessary to provide Sutherland's great sheep flocks with food over the winter months. ${ }^{11}$ These took place in Shinness (1869 to 1884 ) and Kildonan (1879 to $1885)$ and cost the $3^{\text {rd }}$ Duke almost $£ 221,000$, much of which went on the cost of eight Fowler's steam plough sets and wages for the hundreds of labourers required in the field, both to run the engines and work the land. ${ }^{12}$

This article reviews the $3^{\text {rd }}$ Duke's ambitious plan for large-scale land reclamation in Sutherland by delineating the relationship between the three networks that promoted and informed the project. It will examine how these interacted to promote the contemporary culture for agricultural and rural innovation through the development of the Fowlers steam plough. What makes this example of particular interest is the fact that agriculturally and financially, the Sutherland land reclamations were an unconditional failure. ${ }^{13}$ The environment was too challenging for the technology and despite vast financial resources, the

\footnotetext{
${ }^{10}$ E. Richards, 'An Anatomy of the Sutherland fortune: income, consumption, investments and returns, 1780 1880,' Business History, 21 (1979), pp. 46, 52-3; $5^{\text {th }}$ Duke of Sutherland, Looking Back: the autobiography of the $5^{\text {th }}$ Duke of Sutherland (London, 1957), pp. 33-4; Macdonald, 'Agricultural Improvement,' p. 81-2.

${ }^{11}$ Staffordshire County Record Office [hereafter SCRO], Sutherland estates papers, D593/P/24/7/6; W. Orr, Deer Forests, Landlords and Crofters: the western Highlands in Victorian and Edwardian times (Edinburgh, 1982), p. 16.

${ }^{12}$ Steam ploughs were not labour-saving devices: National Library of Scotland [hereafter NLS], Sutherland Estates Papers, Acc. 10225, Reclamations, 5, 'Lairg and Kildonan reclamations: statement as to cost,' 1892; Caunce, 'Mechanisation and Society,' pp. 24, 38.

${ }^{13}$ A. Tindley, 'The Iron Duke:' land reclamation and public relations in Sutherland, 1868-95,' Historical Research, vol. 82, no. 216 (2009), p. 311. Other landlords faced similar failures, for instance the Duke of Northumberland; please see Chambers and Mingay, The Agricultural Revolution, p.177; Caunce, 'Mechanisation and Society,' p. 35; J. Snowball, 'Reports on steam cultivation by machinery let by the landlord as practised on the Northumberland estate of his Grace the Duke of Northumberland,' Journal of the Royal Agricultural Society of England, 2 ${ }^{\text {nd }}$ ser., 6, (1870).
} 
$3^{\text {rd }}$ Duke was, after fifteen years, finally convinced by his advisors that further efforts were futile and irresponsible. This article will interrogate why, despite its essential unfeasibility, the project was pursued, and argue that the momentum created by the dynamic between the three networks involved propelled it forward despite growing evidence of failure. This article therefore uses an inductive approach by examining a particular example of agricultural design innovation and analysing the pertinent social issues in what would have been termed by contemporaries 'entrepreneurial spirit'. 14

\section{Three social networks}

There were three key groups of people who were involved in this process: the $3^{\text {rd }}$ Duke of Sutherland, financier of the scheme and owner of the land; Fowlers and Co., steam plough manufacturers and entrepreneurs, founded and led by prominent British Quakers; and the labour force, the crofters and small tenants who were employed in large numbers to labour on the site in support of the steam technology. After exploring the three key networks which made the Sutherland reclamations possible, there will be an exploration of the dynamic between them and how this contributed to the drive for innovation. The central thesis of this article is that social factors and religious ideologies were fundamental to innovation and that the social and religious networks under scrutiny here had as great an impact on rural as on urban industrial society. ${ }^{15}$ The $3^{\text {rd }}$ Duke of Sutherland - encouraged by a booming agricultural market and prices, examples of heavily investing landlords elsewhere and confidence in new technologies - brought the industrial age to Sutherland through his land

\footnotetext{
${ }^{14}$ Mathias, First Industrial Nation, pp. 141-7.

${ }^{15}$ For a related social constructionist discussion on an alternative technology, please see K. Watt, "Making drain tiles a "home manufacture": agricultural consumers and the social construction of clayworking technology in the 1840s,' Rural History, 13:1 (2002), pp. 41-3.
} 
reclamation and railway building schemes. ${ }^{16}$ Although the confidence of the high Victorian age has been highlighted, this case study also reflects the anxieties that poured out of such high expectations. The drive for 'improvement' - of the land, people - led to anxiety, as did the increasing challenge to aristocratic rule, all of which impacted on perceptions of the Sutherland reclamations, from wider society and among the key players themselves. ${ }^{17}$

\section{'Improvement' and High Farming in the British, European and Imperial contexts}

That the mid to late nineteenth century was an age of continuing innovation and mechanical ingenuity is clear from the wide range of imaginative inventions being produced and developed in this period, facilitated by business and social networks which spread across Britain, Europe and the Empire. ${ }^{18}$ Behind much of this innovation was a continuing drive for 'improvement', particularly in the rural and agricultural context. ${ }^{19}$ Improvement referred to increasingly mechanised and efficient agriculture, either in the development of crops, animal breeds or the quality of the land itself (reclamation), or a more fundamental 'improvement' of people living on the land, their methods and the purpose of agriculture. ${ }^{20}$ This had been supported through the late eighteenth and into the nineteenth century by trailblazers such as Sir John Sinclair, James Caird, and by growing numbers of societies and associations such as

\footnotetext{
${ }^{16}$ C. G. Roberts, 'Sutherland Reclamations,' Journal of the Royal Agricultural Society of England, $2^{\text {nd }}$ ser., 15 (1879), p. 404; C. Hallas, 'The social and economic impact of a rural railway: the Wensleydale line,' Agricultural History Review, 34 (1986), pp. 29-44.

${ }^{17}$ D. Cannadine, The Decline and Fall of the British Aristocracy (London, 1990), pp. 25-32.

${ }^{18}$ H. Bonnett, Saga of the Steam Plough (Newton Abbot, 1974), pp. 24-33; Sheal, 'Land improvement and reclamation,' pp. 110-11.

${ }^{19}$ See for instance, Duke of Bedford, A Great Agricultural Estate: being the story of the origin and administration of Woburn and Thorney (London, 1897); G. E. Mingay, The Victorian Countryside, vol. ii (London, 1981).

${ }^{20}$ J. M. Mackenzie, Empires of Nature and the Nature of Empires: Imperialism, Scotland and the Environment (East Linton, 1997), pp. 66-70.
} 
the Highland and Agricultural Society, and the Royal Agricultural Society. ${ }^{21}$ These bodies funded prizes for innovations and a forum for publication and discussion to disseminate new ideas and practices. ${ }^{22}$ In the context of the Scottish highlands, the most well-known expression of this drive for 'improvement' came in the early to mid nineteenth century with the clearances, the most infamous of which were carried out by the grandmother of the $3^{\text {rd }}$ Duke of Sutherland, the Countess-Duchess of Sutherland, between 1809 and $1825 .^{23}$

The Sutherland ducal family had not lost its taste for improvement by the 1860 s, and they were spurred on benevolent agricultural prices and markets and the boom years of the 1850s, when the introduction of Free Trade, the increasing economic development in the overseas empire and significant investment in and high yields from agriculture created a period known as 'High Farming' ${ }^{24}$ Rents, yields and acreages were increased, as the latest agricultural machinery was developed and utilised, principally in England, but increasingly across the whole of the British Isles and the empire, where steam powered drainage and ploughing spread with great success. ${ }^{25}$ Indeed, it was in Egypt, on the banks of the Nile, that the $3^{\text {rd }}$ Duke of Sutherland first watched a demonstration of steam ploughing undertaken by Max Eyth, a German employee of John Fowlers \& Co. The $3^{\text {rd }}$ Duke was inspired to import the

\footnotetext{
${ }^{21}$ J. Caird, English Agriculture in 1850-51 (London, 1851); I. H. Adams, 'Economic Process and The Scottish Land Surveyor', Imago Mundi 27 (1975), pp. 13-18; I. H. Adams, 'The Agents of Agricultural Change,' in M. L. Parry and T. R. Slater (eds), The Making of the Scottish Countryside (London, 1980), pp. 159-60, 167-9; T. M. Devine, 'The Transformation of Agriculture: cultivation and clearance,' in T. M. Devine, C. H. Lee and G. C. Peden (eds), The Transformation of Scotland: the economy since 1700 (Edinburgh, 2005), pp. 79, 87; Macdonald, 'Agricultural Improvement,' pp. 82-3.

${ }^{22}$ Chambers and Mingay, The Agricultural Revolution, p. 170.

${ }^{23}$ J. Hunter, The Making of the Crofting Community (Edinburgh, 1976), pp. 107-8; E. Richards, The Highland Clearances: people, landlords and rural turmoil (Edinburgh, 2008), pp. 153-4.

${ }^{24}$ Chambers and Mingay, The Agricultural Revolution, p. 171.

${ }^{25} \mathrm{~J}$. Winter, Secure from rash assault: sustaining the Victorian environment (CA, 1999), pp. 62-3. Although High Farming strove for technological efficiency, it was not often economically efficient; see Chambers and Mingay, The Agricultural Revolution, p.177; Macdonald, 'The progress of the early threshing machine,' p. 71.
} 
technology into his estates in the far north of Scotland, working closely with senior Fowler employees, including Eyth, Robert Fowler and George Greig, senior partners in the company and personal friends. ${ }^{26}$

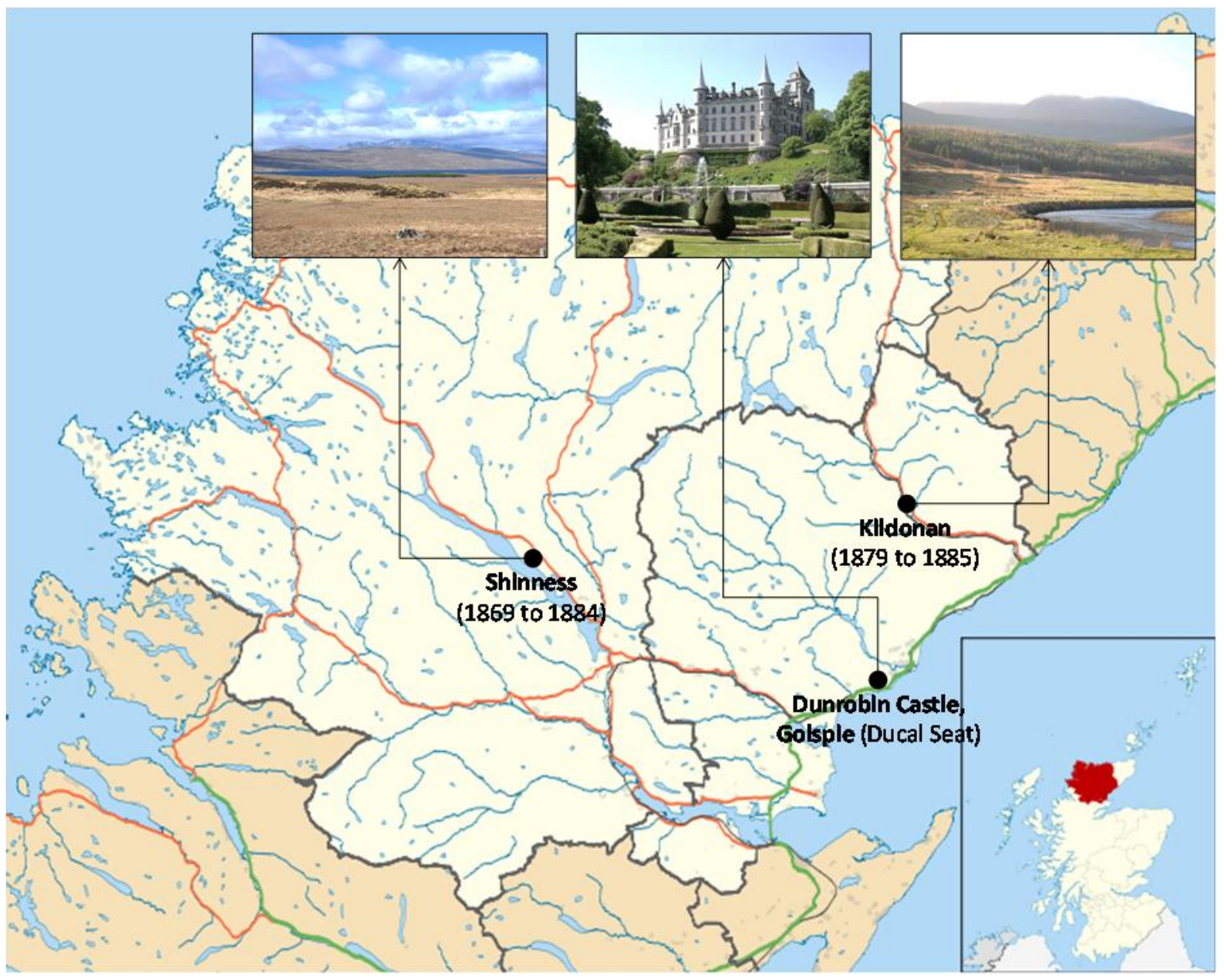

Figure 1: Map of Sutherland with location and dates of land reclamation (Contains

Ordnance Survey data (C) Crown copyright and database right; () Paul Sammonds, used with permission; John Haslam,Wikimedia Commons, Public Domain; @ Timespan, used with permission.)

Steam Ploughing

\footnotetext{
${ }^{26}$ NLS, Acc. 10225, Policy Papers, 69, Wright to Peacock, 14 Jul. 1871; 70, Wright to Peacock, 7 May 1877; see also Lane, Story of the Steam Plough Works, pp. 66-7.
} 
Steam power was the defining technology of the Victorian era. ${ }^{27}$ Its development was initially motivated by the need to pump water from mines, but laterally, its transport, marine and industrial applications were critical to its development - its use in ploughing was on the border of feasibility (it was eventually superseded when the internal combustion engine emerged, although remained in use in some places until after 1945) but is an instructive example of Victorian optimism in the application of technology. ${ }^{28}$

Steam ploughing typically consisted of two traction engines located on either side of a field, and connected with a steel cable. A ploughing implement was dragged between the engines, with each pulling in turn, the plough pivoting around a central axis to allow it to work in two directions. Rocks and stones were then removed and often used to help form drains, boundary dykes and roads as required. The ground would then be broken up, with lime spread prior to crops being sown. ${ }^{29}$

\footnotetext{
${ }^{27}$ Fyfe Steam Powered Knowledge, pp.31-9.

${ }^{28}$ Winter, Secure from Rash Assault, p. 9-11; Bonnett, Farming with Steam, pp.7-8.

${ }^{29}$ Bonnett,Saga of the Steam Plough, pp. 26-7; Winter, Secure from rash assault, p. 63.
} 


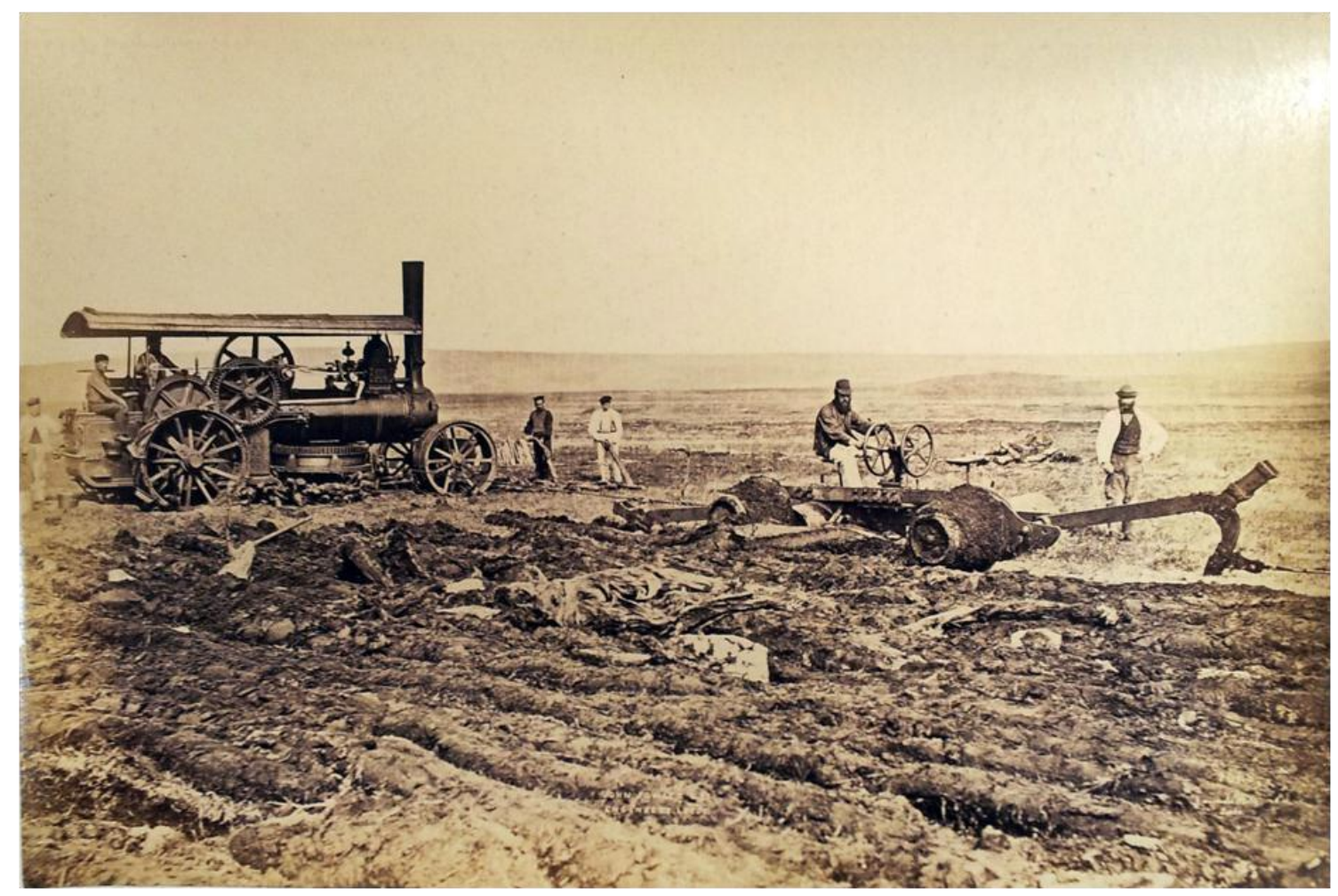

Figure 2: Steam ploughing in Sutherland (the $3^{\text {rd }}$ Duke is seated on the plough) ${ }^{30}$

In the case of the Sutherland reclamations there were particularly significant environmental challenges: the interior of the county consisted mostly of mountains, moors and bogs. Several adaptations were made to the standard plough design to meet these challenges. ${ }^{31}$ An extremely robust plough was required, so a single, large turn-furrow was used to cut through the soil rather than the four or five normally employed. In addition, very broad rollers were used to prevent the plough burying itself in soft ground. This configuration was found to perform well in ground where there were no obstructions, but the majority of land was riddled with rocks and boulders of varying sizes. These caused considerable damage to the share (the cutting head of the plough) on impact. To address this, a revolving coulter was developed. This was a steel disc placed in front of the share, cutting the soil to a depth of two

\footnotetext{
${ }^{30}$ MERL, Fowlers \&Co of Leeds, TR FOW, PH2/33-42, C Series cultivating machinery.

${ }^{31}$ MERL, TR FOW DO2/1 and 2, drawings, registers, 1860s-1892; Bonnett, Farming with Steam, pp.12-13; Lane, Story of the Steam Plough Works, pp. 93-4.
} 
inches below. When meeting a large stone, it would lift the plough over it. A further improvement was 'the Duke's Toothpick', a large iron hook that trailed behind the rear of the plough and lifted any rocks the coulter was unable to move. Extremely large boulders would cause the engine to be backed up and the Toothpick lifted over, with dynamite or manpower used for removal. The ploughs were drawn at a slow speed, with engines operating at double their nominal power to deal with these considerable challenges. ${ }^{32}$

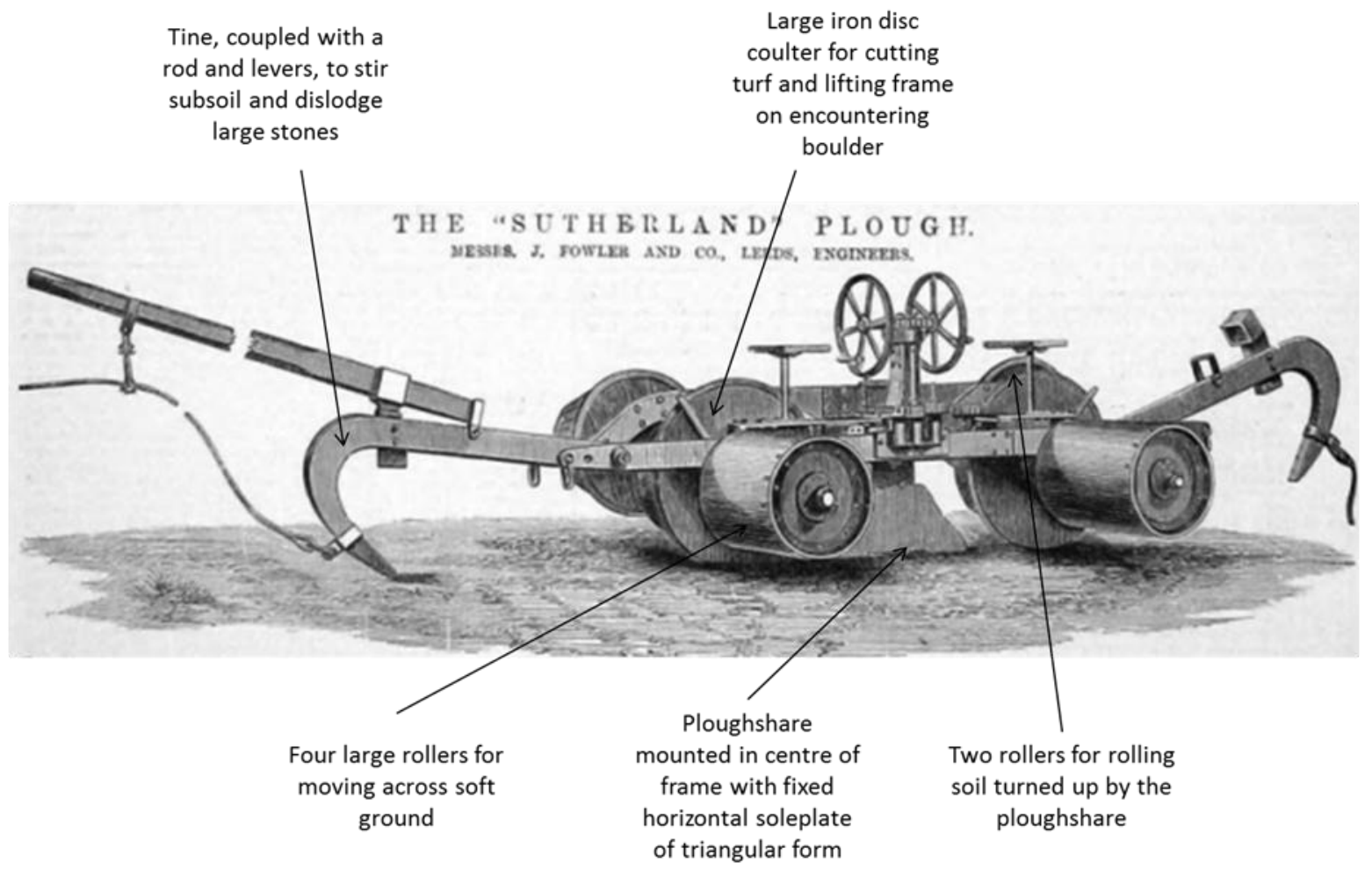

Figure 3: The Sutherland steam plough, with 'Duke's toothpick.'33

There were also a number of ancillary developments around the reclamations. ${ }^{34}$ A sledge for stones allowed up to five tons to be drawn using the steam engines; this was designed to tip the stones out at the end of its run, and in addition to its convenience, dragging across the

\footnotetext{
${ }^{32}$ Roberts, 'Sutherland Reclamations', pp.417-21.

${ }^{33}$ MERL, TR FOW, P2/A22.

${ }^{34}$ Lane, Story of the Steam Plough Works, pp. 96-7.
} 
surface proved beneficial to the broken land, the rubbing action disintegrating it. ${ }^{35}$ With sheep grazing on the surrounding land, it was desirable to fence each field off entirely as the ploughing was taking place. To address this, a folding fence was developed that used steel wire with adjustable stays that could be quickly assembled. To make these sufficiently robust for cattle and horses, coils of wires with 'spikes ... twisted at intervals into them,' were developed - now familiar as barbed wire. ${ }^{36}$ Finally, in order to break down the peat after ploughing, a 'Discer' was invented. While all previous machines tended to get choked by the fibres of peat or turf after it had been loosened, the Discer was able to disintegrate enough of the ploughed field to allow seeding without disturbing the inverted turf. It consisted of a frame with series of discs mounted at an angle to the line of draft, cutting to a depth of two to five inches. Steam ploughing in Sutherland, then, consisted of a series of innovations, not all related to the Sutherland plough itself. ${ }^{37}$

These were the practical opportunities and restrictions offered by the steam plough in the Sutherland context. What this article proposes to do is to examine three social networks which lay behind its identification and utilisation by the Duke of Sutherland: these consist of the aristocratic network, the Quaker network and the crofter network. Although each network was important in different ways, it was the person of the $3^{\text {rd }}$ Duke who linked the networks together and was the key driver in this episode, a role perhaps reflecting his elevated social station.

\footnotetext{
${ }^{35}$ Roberts, 'Sutherland Reclamation,' p.426; Lane, Story of the Steam Plough Works, pp. 96-7.

${ }^{36}$ For more on the technology in the imperial context, see J. Pickard, 'Wire fences in colonial Australia: technology transfer and adaption, 1842-1900,' Rural History, 21:1 (2010), pp. 27-58; Lane, Story of the Steam Plough Works, pp. 96-7.

${ }^{37}$ MERL, TR FOW, letters patent, specifications, licences, agreements and patent litigation, C05/33/8, No. 3151 (1872, 1873); CO5/33/12, No. 319 (1874); C05/33/38, No. 2938 (1877).
} 


\section{Section II: the aristocratic network - British and imperial landowners}

The Sutherland reclamations were led from the front by the $3^{\text {rd }}$ Duke of Sutherland, driven by his passion for the latest steam technologies. This enthusiasm was regarded by contemporaries as somewhat unusual, and perhaps an unwelcome and frivolous diversion from the traditional duties of the landed and titled aristocrat. ${ }^{38}$ For the $3^{\text {rd }}$ Duke himself, and for his advisors, however, the opposite was true: land reclamation was nothing more or less than an extension of the Sutherlands' long-standing programme of 'improvement' on their northern estates. ${ }^{39}$ This section discusses the $3^{\text {rd }}$ Duke's position and ideology as a landowner and peer, his business and imperial networks as a 'gentlemanly capitalist' and imperialist. Lastly, it examines the shifting perceptions of the duties of landlords in this period, and how the $3^{\text {rd }}$ Duke dealt with the contradictory expectations of modern landlordism. Of interest in this particular case study is whether the $3^{\text {rd }}$ Duke matched the expectations of his aristocratic network, or broke away from them, and whether this impacted on the reclamations and the application of innovative steam power to them.

\footnotetext{
${ }^{38}$ For instance, see Punch, 26 Jan. 1878.

${ }^{39}$ A. Tindley, The Sutherland Estate, 1850-1920: aristocratic decline, estate management and land reform (Edinburgh, 2010), p. 4.
} 


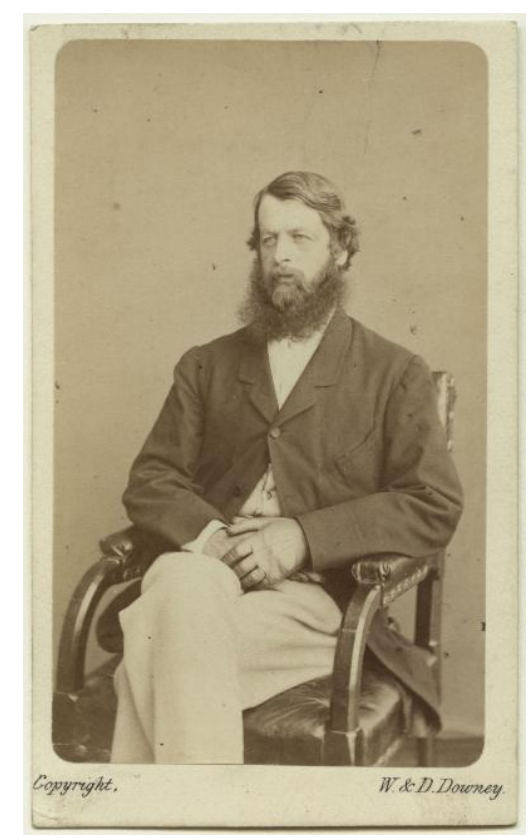

Figure 4: George William Sutherland Leveson-Gower, 3rd Duke of Sutherland (18281892) (@) National Portrait Gallery, London. Used with permission)

The $3^{\text {rd }}$ Duke of Sutherland was not just securely situated within his aristocratic network, he was comfortably within its upper echelons. Although only the eighth richest landowner in Britain and Ireland, he was by far the largest in terms of acreage; indeed, the Sutherlands were the largest landowners in western Europe at this time. ${ }^{40}$ From this the family received $£ 70,000$ per annum from rentals, the bulk of which came from their great sheep farming tenants, the planned beneficiaries of the reclamations. ${ }^{41}$ The family received further income from their business and industrial investments, stocks, shares and consols. When the $3^{\text {rd }}$ Duke inherited in 1861 he commanded an income of around $£ 120,000$ per annum, a vast sum, representing around $£ 5$ million in contemporary terms. ${ }^{42}$

\footnotetext{
${ }^{40}$ Cannadine, Decline and Fall, p. 710.

${ }^{41}$ A. Tindley, Sutherland Estate, p. 4.

${ }^{42}$ Richards, 'An Anatomy,' p. 46.
} 
The Sutherlands enjoyed a high, if not always positive, profile by the 1860s; a profile informed by their own and the wider public and political perception of their efforts in the 'improvement' of their northern estates. Although revolutionary in some senses, the programme of clearances that were the result of these philosophies were rooted in past or traditional perceptions of landowning in the Scottish Highlands and Islands - a paternalistic model based on the duties of a 'Clan Chief' towards his tenantry. Despite the ravages of the post-Jacobite Highlands, when the clan system was broken down by the Hanoverian state, cultural remnants or expectations of what Highland landownership should look like and behave lasted much longer, not just among Highland society more broadly, but among the landed classes themselves. ${ }^{43}$

This created an interesting paradox, whereby contemporary perception, skilfully manipulated by the $3^{\text {rd }}$ Duke and his advisors, linked the traditional images of Highland landownership with radical new technologies, in turn fuelled by the $3^{\text {rd }}$ Duke's imperial business, investment and political networks. In no sense, in other words, were the Sutherland reclamations an organic Highland development: but this was exactly what he and his estate managers portrayed them as - the next step in the continuing programme of 'improvement' that had started with his grandmother and the Sutherland clearances. ${ }^{44}$ This was a very different world to that of John Fowler and other entrepreneurs, who only came to personal wealth after career success rather than through immense inherited wealth and influence. ${ }^{45}$ Landlords like the $3^{\text {rd }}$

\footnotetext{
${ }^{43}$ See for instance, Birmingham Daily Post, 9 Sept. 1872; Inverness Courier, 6 Aug. 1874 for use of this imagery; also, A. I. Macinnes, Clanship, Commerce and the House of Stuart, 1603-1788 (East Linton, 1996), pp. 210-11, 221-8.

${ }^{44}$ See for instance the Sutherland manifesto written by James Loch, architect of the clearances, An Account of the Improvements made on the estates of the Marquis of Stafford (London, 1820); Roberts, 'Sutherland Reclamations,' p.486.

${ }^{45}$ See for instance Times, 7 Sept. 1874; 14 Sept. 1874; Scotsman, 17 Sept. 1872.
} 
Duke often bestrode both worlds: that of traditional, paternalistic landownership and of modern business, industry and empire.

By the 1850s and 1860s, when agricultural and land prices were at their height, shrewd British landowners invested to protect their finances, usually by diversification into nontraditional areas of operation, such as mining, shipping and imperial or overseas investments. ${ }^{46}$ The $3^{\text {rd }}$ Duke of Sutherland was an enthusiastic proponent of this, as a glance at his investment portfolio shows. From ruby mining in Burma, to gas supplies in the USA, to more traditional investments such as the Staffordshire potteries or British railways, the $3^{\text {rd }}$ Duke widened his spheres of economic influence. ${ }^{47}$ It is this context of investment and the ideas behind it that the Sutherland reclamations should be viewed. As already noted, the $3^{\text {rd }}$ Duke first saw the steam plough in action in Egypt, a reflection of the importance of imperial networks to explain how the steam plough got to Sutherland at all. Cain and Hopkins' influential thesis of the 'gentlemanly capitalist' and networks as key drivers of imperial investment are certainly in evidence for the $3^{\text {rd }}$ Duke; he was rich and well connected, and a keen proponent of investment and 'improvement' overseas. ${ }^{48}$ Arguably, the $3^{\text {rd }}$ Duke also applied this mindset to his estate in Sutherland - that it too should be invested in to promote improvement, and that the latest technology could achieve this, where previous attempts, such as the clearances, had failed. ${ }^{49}$

\footnotetext{
${ }^{46}$ D. Cannadine, Aspects of Aristocracy: Grandeur and Decline in Modern Britain (London, 1994), p. 60.

${ }^{47}$ Richards, ‘An Anatomy,' pp. 52-3.

${ }^{48}$ P. J. Cain and A. G. Hopkins, British Imperialism: Innovation and Expansion, 1688-1914 (London, 1993), pp. 23-5, 53-82, 388; For instance in East Africa: J. Forbes Munro, Maritime, Enterprise and Empire: Sir William Mackinnon and his Business Network, 1823-93 (Woodbridge, 2003), pp. 215-21, 287-90.

${ }^{49}$ P. Womack, Improvement and Romance: constructing the myth of the Highlands (Basingstoke, 1989), pp. 748.
} 
Overall, the $3^{\text {rd }}$ Duke was regarded as something of an eccentric, a view bolstered by his lack of the traditional Eton-Oxbridge education, unusual travel destinations and love of steam technology. ${ }^{50}$ It was perhaps this distance between the traditional role of the landed aristocrat and the reality of the $3^{\text {rd }}$ Duke's activities that allowed him the freedom to pursue his steam plough dreams and led to his involvement in inventor and business entrepreneur networks, which featured a strong Quaker element. He did, however, have a deep passion for technology which was a characteristic of the Victorian Era. The explosion of new machines and devices through the Industrial Revolution is startling; it is little wonder that faith in new technologies and developments was so strong. When the Duke's lack of inhibition is coupled with the passion for technology of the time, it provides a strong motive force for the reclamation work - whatever its costs and associated challenges.

\section{Section III: the Quaker network: the Society of Friends and industrial entrepreneurialism applied to the rural context}

This section will delineate the second key network in the story of the Sutherland reclamations, that of a small but influential group of Quaker businessmen, inventors and entrepreneurs who provided the technology that inspired the $3^{\text {rd }}$ Duke to attempt his ambitious scheme in the north of Scotland. For Fowlers, as with many Quakers, a desire for scientific and engineering prowess was matched by an equally important desire to apply that skill to effect the moral and material improvement of the less fortunate in society. John Fowler, founder of the Leeds business, came from a notable family of Norfolk Quakers, and many of his partners and colleagues in business shared his religious convictions, aligning stability and continuity of values to the entrepreneurial spirit of his company. When John Fowler died unexpectedly in 1864 , it was his brother Robert who stepped in to head up the

\footnotetext{
${ }^{50} 5^{\text {th }}$ Duke, Looking Back, pp. 33-5.
} 
firm. He was joined and supported by David Greig, scion of another influential Quaker family, and latterly by George Greig, David's brother. ${ }^{51}$ Indeed it was through the Greigs that the $3^{\text {rd }}$ Duke of Sutherland tapped into this entrepreneurial Quaker network; the Duke had been a friend of David and George's father and enjoyed a close personal friendship with David. $^{52}$

The Society of Friends were a very effective religious, educational, cultural and, of course, economic network in nineteenth century Britain. ${ }^{53}$ As Dissenters, Quakers had long been excluded from many areas of British public life, including direct entry into schools and politics; this forced them to develop their own networks, and this they did very successfully. There has also been speculation as to whether the personal integrity of Quakers, and the translation of this into their business concerns, alongside their refusal to regard business or wealth as ends in themselves, contributed to their success. ${ }^{54}$ The Quaker emphasis on the individual, and every person's development, while being supported within the Quaker collective, was one that had major advantages in the mature industrial economy. They played a critical role in the development of ironworks, for instance, owning between half and threequarters of the ironworks in operation, most of which were connected by partnerships and

\footnotetext{
${ }^{51} 5^{\text {th }}$ Duke, Looking Back, pp. 66-7.

${ }^{52}$ Lane, Story of the Steam Plough Works, p. 90.

${ }^{53}$ J. Walvin, The Quakers: Money and Morals (London, 1998).

${ }^{54}$ L. Hannah, 'The moral economy of business: a historical perspective on ethics and efficiency,' in P. Burke, B. Harrison and P. Slack, Civil Histories: essays presented to Sir Keith Thomas (Oxford, 2000), pp.285-6, 289; Lane, Story of the Steam Plough Works, p. 1.
} 
marriages. ${ }^{55}$ The late 1860 s were the zenith for Quaker industrialists - eventually companies would become too large to be managed by families and through personal liabilities. ${ }^{56}$

The challenges of steam ploughing were significant, and, 'much ingenuity and a good many fortunes were wasted,' in attempts to make it profitable ${ }^{57}$ For John Fowler personally, it was a battle worth fighting. In 1849, as a member of a Quaker delegation, he had visited Ireland, wracked by Famine due to the potato blight and subsequent collapse of the agrarian economy. ${ }^{58}$ He was so affected by the sufferings he saw there that he determined to apply his skills as an inventor, designer and developer of agricultural technology as a means to cheapening the production of food. In this he was successful: in 1857 , he won a prize of $£ 200$ from the Highland Society for, 'the successful trial of his steam tillage apparatus,' in Perthshire. ${ }^{59}$ The late 1850 s and early 1860 s were propitious years to be developing steam cultivation technology, supported by the Egyptian cotton boom as well as a generally buoyant world agricultural market. ${ }^{60}$ Indeed, it was initially the overseas markets that supported the evolution of the steam plough, when home sales remained disappointingly low. This was not for want of effort in publicising the benefits of the new technology, by numerous demonstrations and public lectures, and expansion and investment along Quaker banking and

\footnotetext{
55 J. Walvin, The Quakers: Money and Morals (London, 1998); Hannah, 'Moral economy of business,' p.289, 292.

${ }^{56}$ D. B. Windsor, The Quaker Enterprise: Friends in Business (London, 1980). Often, these networks were based on key families, and this was the case with Fowlers and others. Other businesses they founded included Barclays and Lloyds banks, Allen and Hanbury pharmaceuticals, Huntley and Palmers biscuits, Cadburys, Fry's and Rowntree's chocolate, and Clark's shoes, amongst others.

${ }^{57}$ E. J. T. Collins, Steam in Agriculture (Reading, 1973); C. Tyler, Digging by Steam (Watford, 1977), p.127.

${ }^{58}$ Lane, Story of the Steam Plough Works, 7.

${ }^{59}$ Highland and Agricultural Society, 1878.

${ }^{60}$ Lane, Story of the Steam Plough Works, p. 65.
} 
industrial networks. ${ }^{61}$ In addition to these advantages, intellectual property rights in Britain were the most sophisticated in the world, and provided a significant financial incentive to those named on them. The good management of intellectual property in Britain has been attributed as a key factor in its ascent during the Industrial Revolution and the steam plough is a good illustration of this. ${ }^{62}$ Additionally, the technical emphasis and workshop set-up of industrial education supported innovation, exemplified by the Fowlers premises in Leeds, where apprentices were trained in the skills they would need to become masters. ${ }^{63}$

The development of the steam plough and the resolution of its associated technical challenges by people across the collective is instructive in this instance. Fowlers had little hesitation in committing significant resources to the development of a new plough suitable for the demands of the Sutherland reclamations. The technical expertise of those involved in the project was a product of Britain's entrepreneurial industrial economy. Fowlers was a company experienced in iterative improvement of proven technologies, and the Sutherland plough was an example of reactive designing, where changes were made as necessary based on the problems of undertaking the work. This iterative process relied on the resilience and ingenuity of Fowlers (as well as the Duke's continued financial support) to ensure the work continued, and the ideological motive of utilising technology in order to improve - materially and morally - the position of the rural population.

\footnotetext{
${ }^{61}$ Thomas Fowler, brother of John and Robert, for example, was a cotton trader based in Alexandria and assisted in Fowlers and Co gaining a foothold in that country: Lane, Story of the Steam Plough Works, pp. 63, $68,77$.

${ }^{62}$ Mathias, First Industrial Nation, p. 181-2; Macdonald, 'Progress of the early threshing machine,' p. 6; E. A. Wrigley, Continuity, chance and change: the character of the Industrial Revolution in England (London, 1988); for patents relevant to the Sutherland plough see MERL, TR FOW, C05/33/8, No. 3151 (1872, 1873); CO5/33/12, No. 319 (1874); C05/33/38, No. 2938 (1877).

${ }^{63}$ Bonnett, Saga of the Steam Plough, pp. 65-82.
} 
The $3^{\text {rd }}$ Duke of Sutherland was one of the most important customers Fowlers and Co had from the late 1860s. Although the company had been successfully established, it had faced its fair share of problems, not least the sudden breakdown and death of John Fowler in $1864 .{ }^{64}$ It was testament to the strength of the business and entrepreneurial network that had supported the genesis of the company that sudden reverses in fortune did not bring down the company and it continued to thrive until after World War II. ${ }^{65}$ A key part of this resilience was the financial, entrepreneurial, legal and religious support of the Quaker community in Norfolk, London and Leeds, of whom John and his brother Robert Fowler, David and George Greig were all members. ${ }^{66}$

The Quaker network surrounding Fowlers was not only British, but contained an international dimension too. ${ }^{67}$ One of the key figures in the development of Fowlers as a business generally, and of the relationship and activities in Sutherland particularly, was Max Eyth, a German national and 'humanist' who travelled to Britain for work, attracted by the opportunities afforded by the 'Workshop of the World'. ${ }^{68}$ Eyth's progress from unemployed jobbing engineer to a pillar of a major British firm was a classic example of how effectively Quaker networks could operate to secure the best expertise. Max Eyth was taken on in 1861 and did much to develop the personal relationships and networks that allowed Fowlers \& Co to become the dominant steam cultivating machinery manufacturers over the twenty-one

\footnotetext{
${ }^{64}$ Hannah, 'The moral economy of business,' pp.294-99; Lane, Story of the Steam Plough Works, p. 66.

${ }^{65}$ Lane, Story of the Steam Plough Works, p. 93.

${ }^{66}$ Lane, Story of the Steam Plough Works, pp. 5-6, 61, 93.

${ }^{67}$ For instance, the firm that handled Fowlers' Egyptian business was Briggs and Company of Alexandria, the same firm that also represented Ransomes, Sims \& Jefferies, a Norfolk based Quaker operation; Lane, Story of the Steam Plough Works, p. 65.

${ }^{68}$ Lane, Story of the Steam Plough Works, p. 62.
} 
years he was employed by them. ${ }^{69}$ One of the most important roles Eyth carried out on behalf of the firm were their various overseas operations; he began his career with Fowlers in Egypt, where he first met the $3^{\text {rd }}$ Duke, and made a good impression. ${ }^{70}$ As well as working closely with the $3^{\text {rd }}$ Duke in Sutherland, this relationship garnered the firm important contracts elsewhere, based on the $3^{\text {rd }}$ Duke's recommendations. One of these was the Italian statesman Garibaldi, a personal friend of the Duke's, who had been recommended to Fowlers to fulfil his bold visions of steam cultivation in the Po Valley, in the north of the country. ${ }^{71}$ Eyth spent some months of 1874 there, but also travelled to France, Poland, Russia and Prussia; he was joined in this travelling by Robert Fowler and David Greig, who were in the van of drumming up overseas business for the firm. These results would pay off in the early 1900s as the Fowlers business boomed in Europe, Australia and South Africa. ${ }^{72}$

As well as energetically travelling to their potential custom, the importance of personal networks and friendships remained a strong feature of the Fowlers business model, arguably informed by their Quaker ethos. The relationship between Fowlers and the $3^{\text {rd }}$ Duke is one of the best examples of this: the Duke spent $£ 50,000$ in total on sixteen ploughing engines and seven traction engines, as well as on developing the ploughs to meet the specific needs of the Sutherland terrain. ${ }^{73}$ In return, he had the committed attention of Fowlers employees, Eyth to

\footnotetext{
${ }^{69}$ Lane, Story of the Steam Plough Works, p. 61.

${ }^{70}$ Winter, Secure from rash assault, p.73.

${ }^{71}$ Lane, Story of the Steam Plough Works, p. 90.

72 Pickard, 'Wire fences in colonial Australia,' p. 28 for another successful colonial transfer; Lane, Story of the Steam Plough Works, p. 91.

${ }^{73}$ Lane, Story of the Steam Plough Works, p. 96.
} 
begin with, and then George Greig who was appointed 'reclamations commissioner' and salaried directly by the Sutherland estate. ${ }^{74}$

This relationship was important for the reputation of Fowlers and its ability to generate further business, and is confirmed in the firm's archives. ${ }^{75}$ Indeed, publicising the work they were doing with the $3^{\text {rd }}$ Duke was a key priority for the partners in Fowlers, as demonstrated in the summer of 1874 , when, with the $3^{\text {rd }}$ Duke, they invited some 250 leading Scottish agricultural specialists, alongside members of the Highland and Agricultural Society, to inspect the works at Shinness. A special train was laid on to take the visitors from Inverness to Loch Shin, and a luncheon provided by Fowlers \& Co, at which Robert Fowler and David Greig were present. ${ }^{76}$

The importance of the network of Quaker businessmen, inventors and entrepreneurs in the field of steam power and cultivation was essential to the development and execution of the Sutherland reclamations. Indeed, the Sutherland episode, although unique in the context of the Scottish Highlands, was one of many ambitious schemes being undertaken by Fowlers in Europe, the Middle East and further afield. A relatively small group of men, including the $3^{\text {rd }}$ Duke, supported the Fowler business at home and overseas, and central to this was reputation. Fowlers, structured around its Quaker network and ethos, and a workshop set-up designed to encourage skill and invention, developed an important reputation as a firm of both fair play and experimental innovation. ${ }^{77}$ Having the backing of important figures, such as the $3^{\text {rd }}$ Duke took the firm further, by winning it important contracts, particularly overseas.

\footnotetext{
${ }^{74}$ Roberts, 'Sutherland Reclamation', p. 409.

${ }^{75}$ MERL, TR FOW, CO5/33/8: No. 3151; CO5/33/12: No. 319; C05/33/38, No. 2938; Lane, Story of the Steam Plough Works, p. 93.

${ }^{76}$ MERL, TR FOW, SP2 records of work events; Winter, Secure from rash assault, p.74; Lane, Story of the Steam Plough Works, p. 95; Inverness Courier, 6 Aug. 1874.

${ }^{77}$ Hannah, 'The moral economy of business,' p.299.
} 
The Sutherland reclamations project was, therefore, a key episode for Fowlers; but this project did not occur in a vacuum in the county. For decades before the 1870 s, reclamation had taken place in Sutherland, carried out with the most basic technologies and back-breaking labour, by the small tenants or crofters living on the estate. Their network and response to the $3^{\text {rd }}$ Duke's technological approach will be examined in the next section.

\section{Section IV: the crofter network: clearances, land reclamation and the collective dynamic}

The $3^{\text {rd }}$ Duke's reclamation project was not simply an exercise in the development of agricultural technology; or, indeed, purely to support the agricultural capability of Sutherland's sheep farmers. These were the key reasons given by the $3^{\text {rd }}$ Duke and estate management when the reclamations were in their early years, but they were only a fraction of the motivation behind such a large, disruptive and expensive project. ${ }^{78}$ The Sutherland reclamations were the $3^{\text {rd }}$ Duke's mechanism to demonstrate his credentials as a landowner an investor in and supporter of his estates - who took his duties seriously. ${ }^{79}$ As the reclamations moved from the mid to late 1870 s and into the 1880 s, the Sutherland estate, like all Highland estates, was coming under increasing political pressure and outright attack, as the small tenants, or crofters, who made up the bulk of the labour force on the reclamations scheme, demanded more land, lower rents and security of tenure. ${ }^{80}$ Not all networks surrounding the steam plough and Sutherland reclamations were conducive to its development and application.

\footnotetext{
${ }^{78}$ A. Tindley, 'The Iron Duke,' p. 304.

${ }^{79}$ For example, Times, 12 Sept. 1876; Cannadine, Aspects of Aristocracy, p. 183.

${ }^{80}$ See E. A. Cameron, Land for the People? The British government and the Scottish Highlands, c.1880-1925 (East Linton, 1996).
} 
Most crofters in Sutherland, due to being cleared to uncultivated plots of land in the early nineteenth century, had become expert land reclaimers, using only the most basic tools. One of these was the cas chrom, or foot plough. Made from locally available materials, this is a good example of reactive design to the landscape and circumstances. It nevertheless took long years and backbreaking labour for the Sutherland crofters to clear their small plots of poor land and reclaim it to a level that would allow cultivation or grazing. ${ }^{81}$ The reclamation carried out by crofters from the 1810 s up to the 1880 s was in stark contrast to the radical and technologically advanced plans of the $3^{\text {rd }}$ Duke. A large part of the hubris that surrounded the reclamations was the contrast made between the crofter's 'primitive' techniques and the technologically advanced steam ploughs. ${ }^{82}$ The $3^{\text {rd }}$ Duke saw the reclamations as an opportunity to educate the crofting and larger tenant community in the latest agricultural techniques, the wild and remote landscape of Sutherland only adding to the romance of this confident - perhaps over confident - aim. ${ }^{83}$ The $3^{\text {rd }}$ Duke fundamentally mistook what the Sutherland crofting community wished for by the 1870s; not the latest steam technology, which they both could not possibly afford for themselves or the rent of the land so reclaimed at $£ 73.6 .7$ per acre, but simply more land. ${ }^{84}$ The Sutherland population peaked at the 1861

\footnotetext{
${ }^{81}$ Hunter, Crofting Community, p. 63; C. Tyler and J. Haining, Ploughing by Steam: a history of steam cultivation over the years (Hemel Hampstead, 1970), pp. 23-5; Macdonald, 'Agricultural Improvement,' pp. 837.

${ }^{82}$ Highland News, 23 Jul. 1883, editorial; E. J. T. Collins, 'The rationality of "surplus" agricultural labour: mechanisation in English agriculture in the nineteenth century,' Agricultural History Review, 31 (1987), pp. 3646.

${ }^{83}$ A story related by one of the factors to the Napier Commission about the Duke's confidence ran as follows: 'the Duke of Sutherland one day, standing on the hill pasture, asked me, would it not be a good thing for the employment of the people if we were to set a-going a small farm here, on which we could show the people what crops could be grown by proper trenching and draining and farming.' PP. 1884, xxxii-xxxvi [C. 3980 I-IV] Evidence of the Commission of Inquiry into the Condition of the crofters and cottars of the Highlands and Islands of Scotland, [hereafter Napier Commission Evidence] Evander McIver, p. 1763.

${ }^{84}$ NLS, Acc. 10225, Reclamations, 5, 'Lairg and Kildonan reclamations: statement as to cost,' (1892).
} 
census, and land hunger and congestion dominated the crofting agenda in these decades. ${ }^{85}$ The reclamations were an opportunity for wages, however, with up to one hundred men required to support the work of one ploughing set. Preparing and clearing the fields, managing the engines, manning the ploughs and all the other associated activities of steam ploughing meant that the overall labour involved was huge, even though mechanisation was supposed to make the process more efficient.

While the crofters initially welcomed the wages offered, they were soon disenchanted by the dull nature of the work and the slow rate of progress. Through the early days of the reclamation works, contemporary newspaper reports were quick to blame a recalcitrant workforce for lack of progress, while praising the Duke for his vision. ${ }^{86}$ As the work continued to experience difficulties, the more modest approach of the crofting community began to appear more far-sighted and sustainable and contributed to a changing public perception of the crofting community in the $1880 \mathrm{~s} .{ }^{87}$

\footnotetext{
${ }^{85}$ Census of Scotland, 1911 (Edinburgh, 1912), p.2233; Hunter, Making of the Crofting Community, p.107-8.

${ }^{86}$ See for example Times, 7 Sept. 1874.

${ }^{87}$ See for example, Napier Commission Evidence, pp. 1704-31, 1764-70; Bonnett, Farming with Steam, p.14.
} 


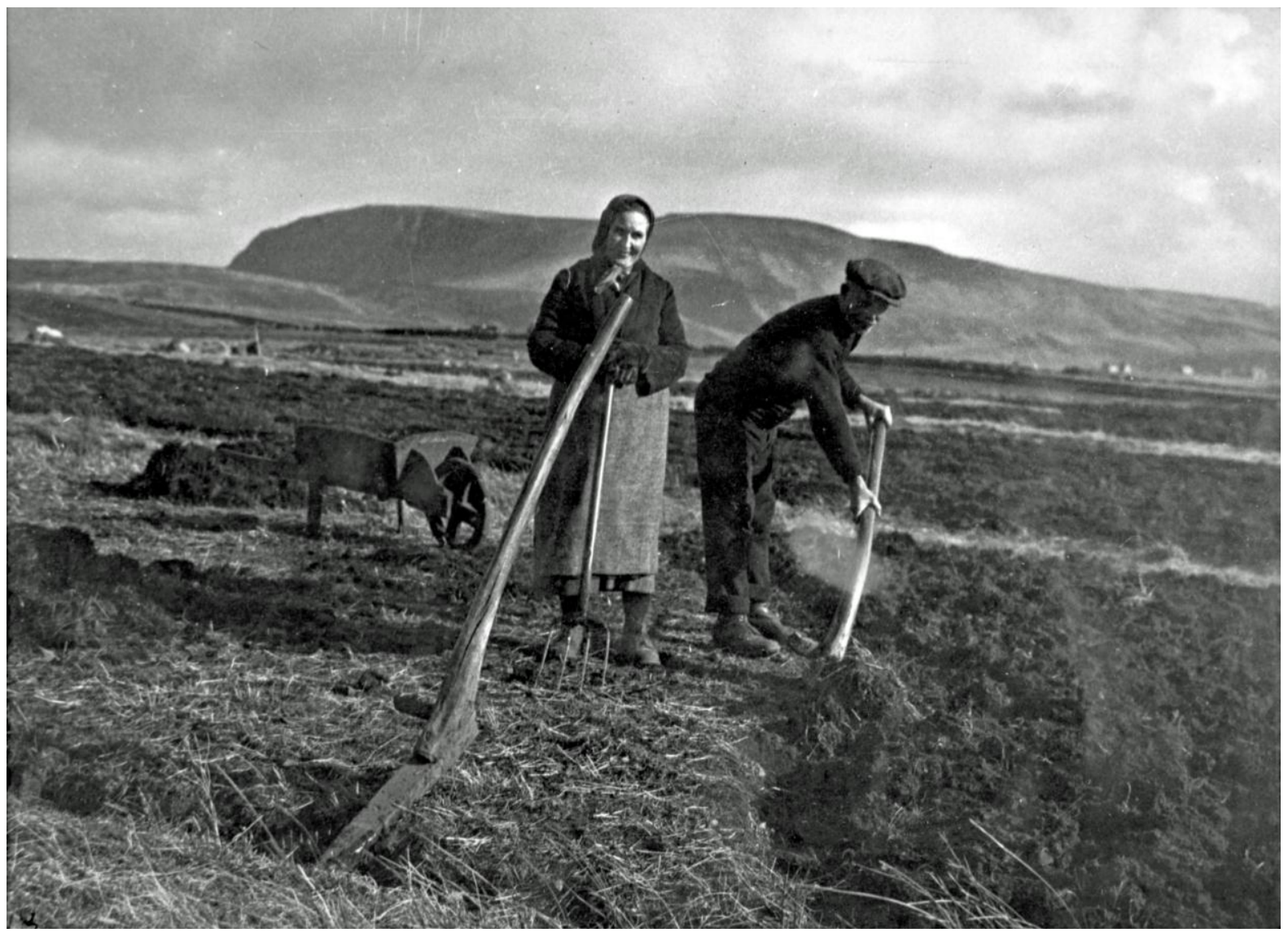

Figure 5: Using a Cas Chrom on Skye - a simple cultivation device made by crofters and used into the $20^{\text {th }}$ century (C I.F. Grant Collection, Highland Folk Museum. Used with permission)

The crofter network linked together thousands of people living on the Sutherland estate, all with certain common features; the Gaelic language and culture, a memory, often bitter, of the clearances, which subsequent generations could see from their hard-won reclaimed land, and an increasing population which added to the congestion and land hunger within crofting communities. ${ }^{88}$ Although nowhere near as powerful as the aristocratic or Quaker networks in the 1870 s, by the early 1880 s the crofter network began to build influence and attract champions, and form a direct challenge to the power of these networks in the Sutherland

\footnotetext{
${ }^{88}$ Hunter, Crofting Community, pp. 131-3; Winter, Secure from rash assault, p.75.
} 
context. ${ }^{89}$ The Sutherland reclamations played a key political role in this febrile atmosphere; the spectacle of the $3^{\text {rd }}$ Duke investing hundreds of thousands of pounds in what was increasingly revealing itself to be a white elephant, both financially and agriculturally, became a political issue by $1883 .{ }^{90}$ Although much of the cost of the reclamations went on wages for labourers and was initially seen as a boon by and for the crofters, criticism soon overtook this support. Although agriculturalists and politicians did praise the intentions of the $3^{\text {rd }}$ Duke, most agreed that they had not been a success in the Sutherland context and their crippling expense meant that they could not be replicated elsewhere. ${ }^{91}$ Despite the initial praise and support for the Duke's vision, general opinion gradually came to regard the work of the steam ploughs, even after various modifications, as ineffective and a waste of money. ${ }^{92}$ The crofter network saw a radical shift in its power and influence over the years of the Sutherland reclamations; from a frustrated and impoverished community, with no connections and no voice in urban politics, to an organised group with political clout, support from the highest circles and the weight of public opinion on its side. Although it provided much of the hard labour required to carry out the reclamations, the labour network was far less supportive of the endeavour than the entrepreneurial and aristocratic networks.

\section{Section V: Conclusion}

\footnotetext{
${ }^{89}$ A. Tindley, Sutherland Estate, pp. 58-64.

${ }^{90}$ A. Tindley, 'The Iron Duke,' pp. 316-7.

${ }^{91}$ Roberts, ‘Sutherland Reclamation,’ p. 441

92 See for instance SCRO, D593/V/6/79, 'Report on the Sutherland Reclamations by the president and secretary of the Scottish Chamber of Agriculture' July 1878; Roberts, 'Sutherland Reclamation,' p. 467; NLS, Acc. 10225, Policy Papers, 93, Loch to Peacock, 1 Dec. 1872.
} 
At first glance, the story of the Sutherland plough is about the $3^{\text {rd }}$ Duke and his folly; however, on closer examination more complex societal factors are often revealed. ${ }^{93}$ While the $3^{\text {rd }}$ Duke was a headstrong enthusiast with significant financial resources, this article has outlined how the use of the steam plough in the reclamation works was the result of not one man acting alone. Instead it was one man acting as the dynamic between three social networks: the aristocratic network, the Quaker and industrial entrepreneurial network, and the crofter network. It is the contention of this paper that the Duke's primary role was to act as a dynamic link across the three, facilitating collaboration in development of the Sutherland plough.

The Duke was representative of Britain's landed aristocracy, a highly active group in Britain's imperial expansion and industrialising economy, often leading from the front in terms of investment in innovation. ${ }^{94}$ The Duke was able to tap into his connections with powerful engineering establishment figures in the shape of the Greig brothers to access the expertise of Fowlers. There was a good deal of faith in the relationship established between the Sutherland estate and Fowlers, which was critical in sustaining the work under challenging circumstances. For their part, Fowlers showed a significant degree of tenacity in mobilising their technical and entrepreneurial skills to find the most appropriate personnel, such as Eyth, to address the problems. While this led to a series of innovations, both in the Sutherland plough itself and the ancillary equipment and processes required in its use, there was a continuing unwillingness within the local crofting community to embrace the use of the machinery. Their ambivalent relationship with the ducal family meant that while they were initially willing to engage with the reclamation works, they soon expressed a desire to return

\footnotetext{
${ }^{93}$ A. H. Van de Ven, 'A community perspective on the emergence of innovations', Journal of Engineering and Technology Management, 10 (1993), pp. 23-51.

${ }^{94}$ Cannadine, Decline and Fall, pp. 133-4.
} 
to their traditional, simpler cultivation techniques. While their resistance caused tension with management at the reclamation sites and attracted the scorn of the local press, given what followed, it was prescient.

In relative terms, the crofters were the weakest social network in this case. Their concerns did not carry the same weight as the prevailing optimism and faith in the deployment of steam power displayed by the Duke and Fowlers, and as a result, the enterprise was initially undertaken with a good deal of enthusiasm. While the Sutherland steam plough included a range of innovative design features and the reclamation process was persisted with over a number of years, it was ultimately unsuccessful. That is not to say that the Sutherland plough itself was not without merit: it was an imposing product, full of unique and highly specialised design features that make distinctive the era of steam ploughing. Even though the design improvements allowed the ploughing at times to operate impressively, the huge numbers of men and crippling ongoing investments required were unsustainable. When it became apparent that the fields which had been ploughed were only moderately fertile and in some cases rapidly returned to their natural state, the work was stopped. ${ }^{95}$

\section{Acknowledgements}

The authors would like to thank the Carnegie Trust for the Universities of Scotland for funding this project, under their small grants scheme (2012).

\footnotetext{
${ }^{95}$ NLS, Acc. 10225, Reclamations, 42, table: 'statement as to cost and rent of reclaimed farms,' 1883.
} 